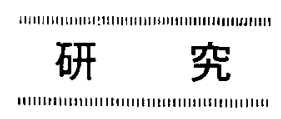

\title{
On the Defect Structure of Rutile
}

\author{
II. Dependence of the Electrical Conductivity of High Purity \\ Polycrystalline Rutile on Equilibrium Oxygen \\ Pressure and Temperature*
}

\author{
Kazumasa Hirajima, ${ }^{* *}$ Tomoaki Sasaki** and Kenzo Hijikata**
}

\begin{abstract}
An investigation has been conducted in order to gain "nearly intrinsic" character on the defect structure of high purity polycrystalline rutile (ca 6 nine), prepared from titanium tetrabutylate as a starting material, in the high oxygen pressure range $10^{-2} \sim 10^{3} \mathrm{mmHg}$ and at the temperature $800^{\circ}$ and $900^{\circ} \mathrm{C}$. Measurement has been made by electrical conductivity ( $\mathrm{dc}$ and $\mathrm{ac}$ ) and thermoelectric power techniques. Since the frequency dispersion of the conductivity was not observed above $800^{\circ} \mathrm{C}$ at the frequency range $1 \sim 100 \mathrm{KHz}$ and $\mathrm{dc}$ conductivity data correspond to those of ac and the sign of the thermo-emf indicates negative, it seems that the carrier is electronic rather than ionic. Over the oxygen pressure range $10^{-2} \sim 10^{3} \mathrm{mmHg}$, the electrical conductivity in nearly intrinsic region accorded well to the relation $\sigma \propto \mathrm{P}_{\mathrm{O}_{2}}{ }^{-1 / 6}$, which is attributed to the predominance of fully ionized oxygen vacancies. It seems that $\mathrm{p}$-type conduction did not belong to the intrinsic character of rutile below atmospheric pressure. The apparent activation energy was found $\mathrm{ca} 1.48 \mathrm{eV}$ in pure oxygen atmosphere at $600^{\circ} \sim 1000^{\circ} \mathrm{C}$.

(Received March 31, 1972)
\end{abstract}

\section{Introduction}

The defect structure of oxygen-deficient rutile has been extensively investigated. There is, however, no agreement among published results. Namely, experimental results have usually been interpreted in terms of either vacancies ${ }^{1-4)}$ or interstitial ions. ${ }^{5-9)}$ Kofstad ${ }^{1}$ ) measured the weight loss $\Delta W$ of rutile to $1227^{\circ} \mathrm{C}$ and concluded that oxygen vacancies are formed from the observed dependence of oxygen pressure $\Delta W \propto P_{\mathrm{O}_{2}}{ }^{-1 / 6}$. Förland ${ }^{2)}$ also observed a $P_{\mathrm{O}_{2}}{ }^{-1 / 6}$ dependence on thermogravimetric measurements in rutile. Bussem and Butler ${ }^{3}$ confirmed the $P_{\mathrm{O}_{2}}{ }^{-1 / 6}$ dependence by weight loss determination. On the other hand, the previous measurements of Assayag ${ }^{5)}$ gave an exponent $-1 / 5$, indicating titanium interstitials. Hurlen ${ }^{6)}$ proposed that titanium interstitials predominate, however, his experimental evidence was scanty. Electron spin resonance experiments were analyzed by Frederikse ${ }^{7}$ ) who concluded that at room temperature the main defects are $\mathrm{Ti}^{3+}$ interstitials. When the electrical conductivity of rutile are plotted as a function of oxygen pressure, $\sigma \propto P_{\mathrm{O}_{2}}{ }^{-1 / m}$, several investigations, close to atmospheric pressure, have given values of $m$ ranging $4 \sim 6.4,8-13$ ) These differences of the values are attributed to reflect the presence of varing amounts of impurities in the rutile used by the different investigators. It might be noted that defect structure of rutile is very dependent on the individual conditions of experiments, such as on impurities in the rutile specimens used and on atmosphere contamination especially

* Reported at the fall meeting of this society, Nagoya, Japan, Nov. 10 (1971).

** Inst. Inorg. Chem., Depart. Chem., Nihon Univ., 3-25-40 Sakurajosui Setagaya-ku Tokyo Japan. 
at low temperatures. The reported results have not been carried out under extremely high purity of specimen and atmosphere. In order to gain precise information for "nearly intrinsic" character of rutile, it is essential either to use extremely high purity material or to conduct experiments in which the impurity content can be shown to have little effect. The object of the present investigation is to study the influence of oxygen partial pressure on the electrical conductivity of high purity specimen, prepared from titanium tetra-butylate, at low temperatures and high oxygen pressures.

\section{Experimental Procedures}

\section{II-1 Specimens}

The powder of high purity oxide (rutile) was prepared from titanium tetra-butylate (T.B.T.100; Nihon Soda Co. Ltd., Tokyo, Japan).

The white precipitate, which was obtained by hydrolysis of titanium tetra-butylate with pure water, was filtered, washed with tripply distilled water, dried in air at ca $200^{\circ} \mathrm{C}$, and calcined in a quartz crucible at $1000^{\circ} \mathrm{C}$ for $1 \mathrm{hr}$ in air, and then cooled slowly in an electric furnace with Kanthal heater.

The X-ray diffraction patterns of the powders indicated a well crystallized structure of rutile.

Table 1 Spectrographic analysis of rutile from T.B.T.

\begin{tabular}{cccccccccc}
\hline Ti & $\mathrm{Cr}$ & $\mathrm{Si}$ & $\mathrm{V}$ & $\mathrm{Fe}$ & $\mathrm{Ca}$ & $\mathrm{Mg}$ & $\mathrm{Mn}$ & $\mathrm{Ni}$ & $\mathrm{Mo}$ \\
\hline V.S. & N.D. & V.V.W. & N.D. & N.D. & N.D. & N.D. & N.D. & N.D. & N.D. \\
\hline
\end{tabular}

N.D.: not detected, p.p.m. under

With a small addition of ethyl alcohol as a binder, the powders were compacted into tablets at ca $2000 \mathrm{~kg} / \mathrm{cm}^{2}$. After removing the binder and the contamination from the steel mould, the compacts were packed in the same rutile powders, and sintered in a mullite tube with a SiC heater at $1400^{\circ} \mathrm{C}$ for $20 \mathrm{hr}$ in air. The apparent densities of sintered specimens were greater than $80 \%$ of theoreticals. The specimens were polished and shaped into disks ca $8 \mathrm{~mm}$ in diameter by $3 \mathrm{~mm}$ thick. The spectrographic analysis* of the sintered specimen indicated that the silicon contaminated from an agate mortar only increased to v.v.w., and yet the remaining impurities were unchanged (Table 1).

Platinum was evaporated in vacuum on the both sides of the disk as electrodes.

\section{II-2 Apparatus and Atmosphere Control}

Fig. 1 shows the schematic diagram of the apparatus for the measurements of electrical conductivity and thermoelectric power. All measurements were made in a specially designed alumina tube. The platinum-evaporated specimen disk sandwitched between the platinum plates is shown in Fig. 2. Two thermocouples $(0.3 \mathrm{~mm} \phi \mathrm{Pt}-\mathrm{Pt} 13 \% \mathrm{Rh})$ with platinum wires as current

* J.A. CO., Emission Spectrograph with a diffraction grating, Ebert mount $3.4 \mathrm{~m}$. 


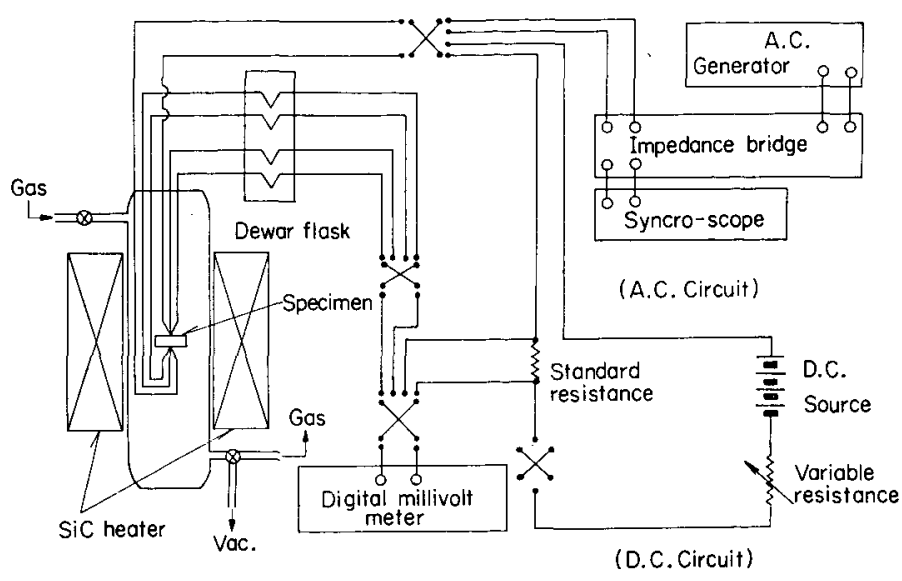

Fig. 1 Schematic diagram of apparatus for electrical conductivity.

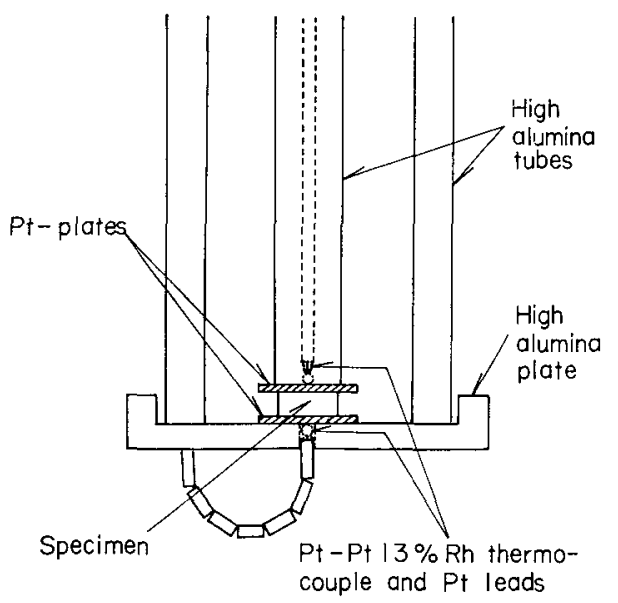

Fig. 2 Specimen holder.

leads were contacted to each electrode. The platinum arms of the thermocouples are used to determine ac conductivity, dc conductivity and Seebeck voltage.

The specimen temperature could be controlled within $\pm 0.3^{\circ} \mathrm{C}$. For the high oxygen pressure (e.g. oxygen partial pressure: 150 and $760 \mathrm{mmHg}$ ), an oxygen-nitrogen gas mixture was used. Each gas was dried (dew point: $-50^{\circ} \mathrm{C}$ ) by molecular sieves, ${ }^{*}$ and after passing through the calibrated flow-meters, gases were mixed and introduced into the chamber for the electrical measurements (ca $250 \mathrm{cc} / \mathrm{min}$ ). For low oxygen pressure, a vacuum pumping system with a Pirani gauge was used.

\section{II-3 Measurements}

The electrical conductivity measurements (both ac and dc) based on a two-terminal method. The ac conductivity was measured directly by an impedance bridge** applying $1 \mathrm{KHz}$ to the specimens in all runs. All the dc fields used were below $6 \mathrm{~V} / \mathrm{cm}$ to ensure ohmic behavior and the

* molecular sieves $5 \mathrm{~A}$.

** Model AS-7130, Ando Electric Co., Ltd., Tokyo, Japan. 
dc readings were taken in both direction and averaged. The ac and dc conductivities were obtained on heating and cooling with a good reproducibility. The measurements were approched in the direction of both increasing and decreasing oxygen pressures at each constant temperature.

Equilibrium points were taken after specimen resistance stabilized for $1 \mathrm{hr}$. Their values, however, remained constant even in $20 \mathrm{hr}$ or more in all experimental conditions.

The thermoelectric power $Q$ is defined as the proportionality factor between the electrical field and the temperature gradient existing in a specimen with the condition that electrical current density is zero. Thus $Q$ is given by the following equation:

$$
\Delta V=Q \cdot \Delta T
$$

where $\Delta V, \Delta T, Q$ are respectively the specimen emf, the temperature difference between the two ends of the specimen, and the thermoelectric power of the specimen. Plot of $\Delta V$ vs $\Delta T$ were made at various temperatures at fixed $P_{\mathrm{O}_{2}}$ and $Q$ obtained from the slope using the expression. Usually three data points were used to determine the slope. The temperature gradient varied ca $5^{\circ} \sim 20^{\circ} \mathrm{C} /$ $\mathrm{cm}$ was established by moving the furnace. After moving the furnace, ca $1 \mathrm{hr}$ had to be allowed for the specimen to reach to equilibrium. Temperatures and emf of the specimen were both measured with a digital millivolt meter.*

\section{Results}

The electrical conductivity of the sintered rutile compact was observed to follow the form $\sigma \propto \exp (-\Delta H \mid K T)$. A plot of $\log \sigma$ vs the reciprocal of absolute temperature at $760 \mathrm{~mm} \mathrm{Hg}$ of the oxygen pressure is displayed in Fig. 3. The reproducibility was obtained in all used atmospheres on heating and cooling and the thermal hysteresis was not observed. The data are well represented by a straight line having a $1.48 \mathrm{eV}$ slope in the temperature ranges $600^{\circ} \sim 1000^{\circ} \mathrm{C}$ except at $500^{\circ} \mathrm{C}$. The frequency dispersion of the conductivity was observed at $700^{\circ} \mathrm{C}$ as shown by isobar

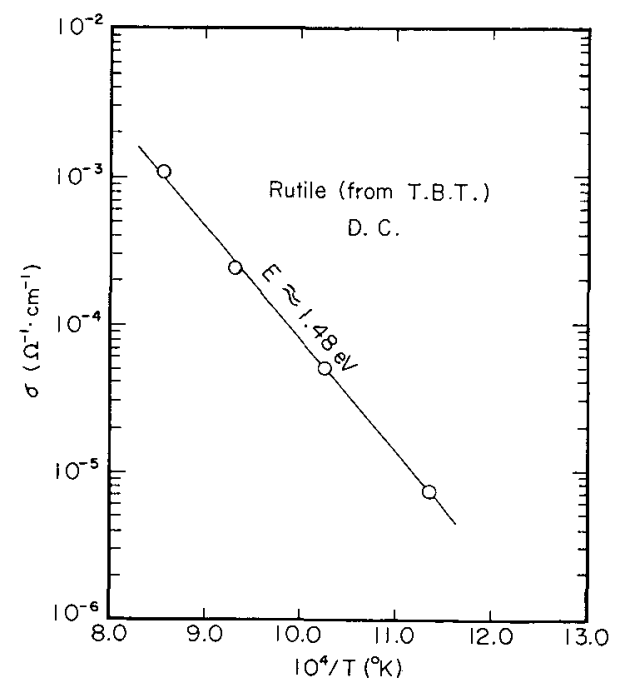

Fig. 3 The electrical conductivity vs. the reciprocal of absolute temperature at $760 \mathrm{mmHg}$ of oxygen partial pressure for rutile.

* Type 2805, $0.1 \mu \mathrm{V}$ (max. sensitivity/1 digit), Yokogawa Electric Works, Ltd., Tokyo, Japan. 


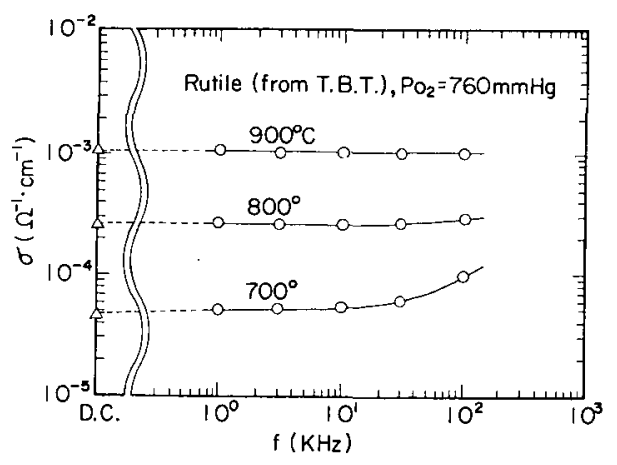

Fig. 4 Frcquency dispersion for rutile.

relation in Fig. 4. Above $800^{\circ} \mathrm{C}$, the dc conductivity data corresponded to those of ac, while below $700^{\circ} \mathrm{C}$ the ac conductivity were slightly higher than $\mathrm{dc}$ values on the same run. When the dc conductivity measurements were performed at $760 \mathrm{mmHg}$ oxygen pressure under $500^{\circ} \mathrm{C}$, the dc voltage between both ends of specimen changed slowly for ca 6 min from the time that the current was turned on. In the case of specimen without platinum-evapolated electrodes, voltage changes occured over much longer periods, usually ca $50 \mathrm{~min}$ or more.

In the thermoelectric power measurements, the cooler end of the specimen was always negative with respect to hotter end. This fact indicates negative charge carriers in pure oxygen, but the quantitative values could not be obtained with a reproducibility.

The electrical conductivity as a function of oxygen partial pressure was found to obey the relation $\sigma=K \cdot P_{\mathrm{O}_{2}}{ }^{-1 / m}$, as given in Fig. 5. Both the $800^{\circ}$ and $900^{\circ} \mathrm{C}$ curves are characterized by $m=6.0$.

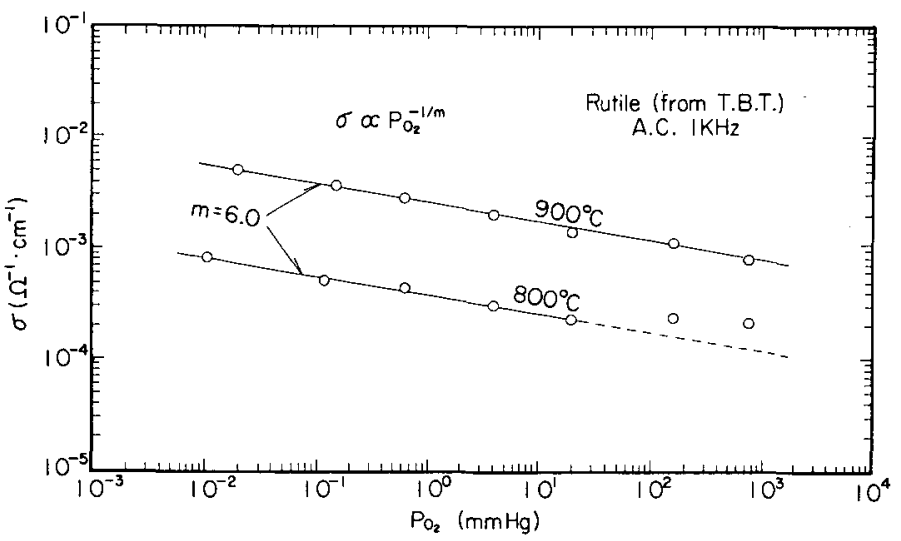

Fig. 5 The logarithms of electrical conductivity vs. the logarithms of oxygen partial pressure for rutile.

\section{Discussion}

\section{IV-1 Defect Structure}

The conductivity curve of Fig. 3 indicates that there is only a conduction mechanism in the high oxygen partial pressure $\left(760 \mathrm{mmHg} \mathrm{O}_{2}\right)$. 
The negative sign of the thermo-emf indicates that the defects are either electrons which are free to move through the crystal or are negatively charged ionic defects. The fact that frequency dispersion is not observed above $800^{\circ} \mathrm{C}$ suggests that the conduction is electronic rather than ionic. In addition, free electrons are associated with donor-type defects which are oxygen deficient defects. The electrical conductivity increased with decreased oxygen pressures, which indicates oxygen deficient defects are responsible. In the observed pressure dependence, the slope $-1 / 6$ is attributed to the predominance of doubly ionized oxygen vacancies according to the following equation:

$$
1 / 2 \mathrm{TiO}_{2} \rightleftharpoons 1 / 2 \mathrm{Ti} \text {-ion (1attice) }+\mathrm{AV}+2 e^{-}+1 / 2 \mathrm{O}_{2} \text { (gas), }
$$

therefore, by the chemical equilibrium theory,

$$
P_{\mathrm{O}_{2}}{ }^{-1 / 2}=K(T) \cdot[\mathrm{AV}] \cdot\left[e^{-}\right]^{2} \text {. }
$$

If the neutrality condition can be simplified to

$$
\begin{aligned}
{[\mathrm{AV}] } & =2\left[e^{-}\right], \quad \text { then } \\
P_{\mathrm{O}_{2}}{ }^{-1 / 2} & =K^{\prime}(T) \cdot\left[e^{-}\right] \cdot\left[e^{-}\right]^{2}, \\
& =K(T) \cdot\left[e^{-}\right]^{3} . \\
\sigma & =\left[e^{-}\right] \cdot q \cdot \mu(T)=K^{\prime \prime}(T) \cdot P_{\mathrm{O}_{2}}{ }^{-1 / 6},
\end{aligned}
$$

where $e^{-}$is an electron in the conduction band, AV is an oxygen vacancy from which both electrons have been exited, $q$ is carrier concentration, and $\mu$ is mobility, respectively.

A plot of the electrical conductivity as a function of the reciprocal absolute temperature gives a value for the activation energy of the intrinsic conductivity. An approximately straight line relation was obtained with an activation energy of $1.48 \mathrm{eV}$. This indicates that the intrinsic energy gap in rutile is equal to $2.96 \mathrm{eV}$. As a comparison it has been found that intrinsic energy gap in rutile has a value of $3.04 \sim 3.12 \mathrm{eV} .{ }^{12,14,15)}$.Winter ${ }^{16)}$ studied the kinetics of exchange of oxygen-18 for the several oxides, and the activation energy of exchange reaction for rutile was found $35 \mathrm{kcal} / \mathrm{mol} \approx 1.52 \mathrm{eV}$ ) in the temperature range $500^{\circ} \sim 750^{\circ} \mathrm{C}$.

Studies of electrical conductivity as a function of oxygen pressure ( $1 \mathrm{~atm} \sim \mathrm{CO}-\mathrm{CO}_{2}$ mixtures) at $1000^{\circ} \sim 1500^{\circ} \mathrm{C}$ by Tannhauser $^{8}$ and Blumenthal $e t a l^{9}$, have shown that the oxygen pressure dependence, $\sigma \propto P_{\mathrm{O}_{2}}{ }^{-1 / m}$, is characterized by values of $m$ ranging from $4 \sim 5$ in $\mathrm{CO}-\mathrm{CO}_{2}$ mixtures to $5 \sim 6$ at atmospheric and subatmospheric pressures. The results in the $\mathrm{CO}-\mathrm{CO}_{2}$ mixtures have been interpreted in terms of a defect structure model involving tri- and tetra-valent interstitial titanium ions. By Blumenthal et al, ${ }^{9}$ however, the electrical conductivity of rutile in air below ca $950^{\circ} \mathrm{C}$ appears on the basis of his investigation to be impurity-controlled due to the presence of aluminum rather than intrinsic conduction. Yahia ${ }^{13}$ ) reported that the oxygen ion vacancy model seemed to predominate at pressure above $10 \mathrm{mmHg}$ in the temperature range $950^{\circ} \sim$ $1212^{\circ} \mathrm{C}$, while at lower oxygen pressures a model involving titanium interstitial was dominant. It seems likely to be questionable that specimen used in his investigation contained total impurity ca $700 \mathrm{ppm}$. Delmaire et $a l^{17}$ ) also reported $-1 / 6$ dependence, however, it was not clearly described at all for the experimental details. Ludolph ${ }^{12}$ ) obtained values of $m$ ranging $4.9 \sim 5.7$ at $719^{\circ} \sim 944^{\circ} \mathrm{C}$, but impurity of specimen used was not indicated. Thus, it is unreasonable to compare the present results with theirs above mentioned. From the results of conductivity measurement of rutile by Greener et al, ${ }^{4)}$ impurity-controlled defects were dominant in the lower temperature region $600^{\circ} \sim 900^{\circ} \mathrm{C}$. 
It seems that the authors could succeed in measuring "nearly intrinsic" conductivity of rutile, because the relation $\log \sigma$ vs $1 / T$ was well represented by a straight line having a slope $1.48 \mathrm{eV}$ as shown in Fig. 3 in the temperature range $600^{\circ} \sim 1000^{\circ} \mathrm{C}$, and the sign of the thermo-emf indicated negative in all temperature ranges. As to the possibility of coexistence with interstitial ions shown by Kofstad ${ }^{27)}$, the authors did not carry on the electrical conductivity measurements above $1000^{\circ} \mathrm{C}$, because the diffusion of platinum electrode into specimen was observed remarkably in higher temperatures. Thus the authors could not make out whether interstitial titanium ions coexsist at the same time or not.

Recently, Innami $e t a l^{28}$ ) has found that the linear shrinkage and the specific resistance during sintering for the same rutile powders used for the present experiment were very affected by the oxygen partial pressure. At $\mathrm{N}_{2}$ atmosphere $\left(\approx 10^{-3} \mathrm{mmHg}\right.$ oxygen partial pressure), the linear shrinkage and the electrical conductivity increased rather than at air atmosphere. These consistent with the present results of electrical conductivity measurements. Therefore, it may be noted that the defect structure of high purity rutile involved oxygen vacancies.

\section{IV-2 Impurity Effect}

Earlier studies, by the authors, ${ }^{18)}$ of the electrical properties of polycrystalline rutile from $\mathrm{TiCl}_{4}$ indicates the $\mathrm{p}$-conduction. The results are shown in Fig. 6 . The curves are shown to be an amphoteric semiconductor with the region of predominant hole conduction shifting to higher pressures at lower temperatures. About this p-conduction, Kofstad ${ }^{19)}$ and Pearson ${ }^{20)}$ also found. It is of interest to note that iron-doped rutile exhibits an amphoteric semiconductor in a certain pressure range at high temperatures ${ }^{12}$ ). A similar p-type character was found in aluminiumdoped rutile by Yahia. ${ }^{13)}$ Hauffe $^{11)}$ and Hurlen ${ }^{6}$ also observed the p-type conductivity of chromium-doped rutile, and the authors ${ }^{18)}$ also confirmed similar behavior of chromium-doped rutile from the thermoelectric power and pressure dependence of conductivity below $1000^{\circ} \mathrm{C}$.

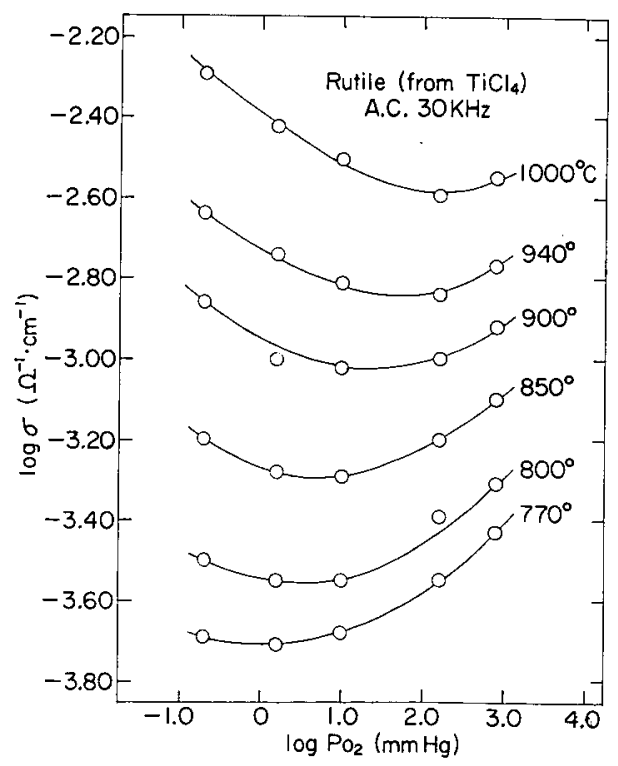

Fig. 6 Isothermal relation between the logarithms of the conductivity and the logarithms of $P_{\mathrm{O}_{2}}$ in the temperature range $770^{\circ} \sim 1000^{\circ} \mathrm{C}$. 
Table 2 Spectrographic analysis of rutile from $\mathrm{TiCl}_{4}$.

\begin{tabular}{cccccccccc}
\hline Ti & $\mathrm{Cr}$ & $\mathrm{Si}$ & $\mathrm{V}$ & $\mathrm{Fe}$ & $\mathrm{Ca}$ & $\mathrm{Mg}$ & $\mathrm{Mn}$ & $\mathrm{Ni}$ & Mo \\
\hline V.S. & N.D. & W. & N.D. & N.D. & V.W. & V.W. & N.D. & N.D. & N.D. \\
\hline
\end{tabular}

N.D.: not detected, p.p.m. under

It seems that p-type behavior, observed in the case of previous work, ${ }^{18)}$ happened on the interaction of the defects produced by the various impurities. P-type character was not found in the present case of high purity rutile. Therefore, it appears that p-type conduction did not belong to the intrinsic behavior of rutile below atmospheric pressure. Results of spectrographic analysis of rutile powders prepared from $\mathrm{TiCl}_{4}$ are given in Table 2.

Recently, there are some reports for the influence of the atmosphere contamination on the experiments. Aronson ${ }^{21)}$ and Kofstad and Ruzicka ${ }^{22}$ examined oxygen deficiency in $\mathrm{ZrO}_{2}$ as a function of temperature $\left(<1300^{\circ} \mathrm{C}\right)$ and of oxygen partial pressure, using $\mathrm{H}_{2}-\mathrm{H}_{2} \mathrm{O}$ and CO$\mathrm{CO}_{2}$ gas mixtures, and both studies produced uncertain results. Hussey and Smeltzer ${ }^{23)}$, who studied the oxidation of $\mathrm{Zr}$ by $\mathrm{CO}-\mathrm{CO}_{2}$, indicated that this gas mixture may give unreliable results with $\mathrm{ZrO}_{2}$. By Carniglia et al, ${ }^{24)}$ consistent results were obtained when $\mathrm{O}_{2}$-inert gas mixtures were used, but use of $\mathrm{H}_{2}-\mathrm{H}_{2} \mathrm{O}$ and $\mathrm{CO}-\mathrm{CO}_{2}$ at $1000^{\circ} \sim 1200^{\circ} \mathrm{C}$ gave abnormal and, in the latter case, erratic data. Iguchi and Yajima ${ }^{25}$ reported that the rutile specimens reduced in vacuum with diffusion pump are contaminated by pump oil. Any carbon introduced with pump oil might influence on the electrical properties near-stoichiometric region or in the n-type region, as suggested by Pope and Simkovich. ${ }^{26}$ ) The side reactions in these atmospheres are inferred.

\section{IV-3 Homogeneous Range of Rutile}

The general problem of the stability of compounds which exhibit an apparently large deviation from the stoichiometric composition has been reviewed by Anderson et a ${ }^{29)}$ and Wadsley. ${ }^{30)}$ A continuous series of phases of rutile having the basic rutile structure has been identified for compositions corresponding to $\mathrm{Ti}_{n} \mathrm{O}_{2 n-1}$, where possibly $\mathrm{n} \rightarrow \infty$. Anderson et al ${ }^{31}$ ) put the limit of homogeneity at higher than $\mathrm{TiO}_{1.96}$. More recently, Straumanis et al ${ }^{32}$ ) have placed the limit at $\mathrm{TiO}_{1.983}$ for the specimens quenched from $1400^{\circ} \mathrm{C}$. Bursil and $\mathrm{Hyde}^{33)}$ suggest the existence of a new family of ordered phases, probably $\mathrm{Ti}_{n} \mathrm{O}_{2 n-1}(n=15 \cdots 36)$ derived from quenched rutile (ca 99.9\%) by means of electron microscopic observation. These studies were made for the quenched samples but a thermodynamic information is very scare. By Bulmenthal and Whitmore ${ }^{34)}$, electromotive forces on galvanic cells which utilized solid electrolytes were measured to determine the homogeneous range of rutile at $900^{\circ}$ and $1000^{\circ} \mathrm{C}$. The cell voltage is plotted as a function of the $\mathrm{O} / \mathrm{Ti}$ ratio at the two temperatures. In the case of electrode compositions with $\mathrm{O} / \mathrm{Ti}$ ratios ca $1.998 \sim 1.992$, the cell emf is a function of specimen composition, siginifying the existence of a single-phase region (probably nonstoichiometric rutile) and specimens with O/Ti ratio lying ca 1.992 1.968 exhibited essentially constant emf's, providing further evidence that a two-phase region exists over this compositional range. In a large number of these studies, the $\mathrm{O} / \mathrm{Ti}$ ratio has been determined by the thermogravimetirc method. In this kind 
of investigation, no experiments have yet been made in order to determine the homogeneous range as a function of oxygen partial pressure in a certain temperature.

\section{Summary}

1) The electrical conductivity of high purity polycrystalline rutile prepared from T.B.T. was determined as a function of the oxygen partial pressure $\left(10^{-2} \sim 10^{3} \mathrm{mmHg}\right)$ at $800^{\circ}$ and $900^{\circ} \mathrm{C}$. The electrical conductivity has been found proportional to $P_{\mathrm{O}_{2}}{ }^{-1 / 6}$.

2) The frequency dispersion of the conductivity was not observed at $800^{\circ}$ and $900^{\circ} \mathrm{C}$, and the $\mathrm{dc}$ conductivity data corresponded to those of ac.

3) The relation $\log \sigma$ vs $1 / T$ was well represented by a straight line having a slope $1.48 \mathrm{eV}$ in pure oxygen gas and in the temperature range $600^{\circ} \sim 1000^{\circ} \mathrm{C}$.

4) In the thermoelectric power measurements, the cooler end of the specimen was always negative with respect to the hotter end indicating negative charge carriers, electrons, but the quantitative values could not be obtained with a reproducibility.

5) It may be concluded that the defect of rutile with a "nearly intrinsic" character involves oxygen vacancies at $800^{\circ}$ and $900^{\circ} \mathrm{C}$ in the oxygen partial pressure $10^{-2} \sim 10^{3} \mathrm{mmHg}$, and it appears to imply that p-type conduction did not belong to the intrinsic behavior of rutile below atmospheric pressure.

\section{Acknowlegement}

The authors wish to thank Dr. K. Itsuki and Mr. T. Ishikawa, Mitsubishi Central Research Institute, Mitsubishi Metal Mining Co., Ltd., Oomiya, Japan, for the spectrographic analysis and also indebted to Osaka Titanium Co., Ltd., Osaka, Japan, for kindly supplying titanium tetrachloride.

\section{References}

1) P. Kofstad: J. Phys. Chem. Solids, 23 (1962), 1579.

2) K. S. Förland: Acta Chem. Scand., 18 (1964), 1267.

3) W. R. Bussem and S. R. Butler: Kinetics of High Temperature Processes, ed. E. Kingery, John Wiley, N.Y., (1958), 13.

4) E. H. Greener, F. J. Barone and W. M. Hirthe: J. Am. Ceram. Soc., 48 (1965), 623.

5) P. Assayag, M. Dodem and R. Faivre: C.R. Acad. Sci. Paris, 240 (1955), 1212.

6) T. Hurlen: Acta Chem. Scand., 13 (1959), 365.

7) H. P. R. Frederikse: J. Appl. Phys. Suppl,, 32 (1961), 2211.

8) D. S. Tannhauser: Solid St. Commun., 1 (1963), 223.

9) R. N. Blumenthal, J. Coburn, J. Baukus and W. M. Hirthe: J. Phys. Chem. Solids, 27 (1966), 643; J. Electrochem. Soc., 114 (1967), 172.

10) M. E. Earle: Phys. Rev., 61 (1942), 56.

11) K. Hauffe: Reaktionen in und an Festen Stoffen, Springer Verlag, Berlin (1955).

12) J. Rudolph: Z. Naturforschung, 14a (1959), 727.

13) J. Yahia: Phys. Rev., 130 (1963), 1711.

14) D. C. Cronemeyer: Phys. Rev., 87 (1952), 876; 113 (1959), 1222.

15) F. A. Grant: Revs. Mod., 31 (1959), 646.

16) E. R. S. Winter: J. Chem. Soc. (A) (1968), 2889.

17) J. P. Delmaire, N. Wallet: C.R. Acad. Sci., Paris. Ser., c264 (1967), 1290.

18) K. Hirajima, T. Sasaki and K. Hijikata: Reported at the spring meeting of this society, Tokyo, May, (1971).

19) P. Kofstad: J. Electrochem. Soc, 109 (1962), 776.

20) A. D. Pearson: J. Phys. Chem. Solids, 5 (1958), 316. 
21) S. Aronson: J. Electrochem. Soc., 108 (1961), 313.

22) P. Kofstad, D. J. Ruzicka: ibid., 110 (1963), 181.

23) R. J. Hussey, W. W. Smeltzer: ibid., 112 (1965), 554.

24) S. C. Carniglia, S. D. Brown and T. F. Schroeder: J. Am. Ceram. Soc., 54 (1971), 13.

25) E. Iguchi, K. Yajima: J. Inst. Metals, Japan, 35 (1971), 395.

26) J. M. Pope, G. Simkovich: Paper No. 111, presented at the Detroit Meeting of the Society, Oct. 5-9 (1969).

27) P. Kofstad: J. Less-Common Metals, 13 (1967), 635.

28) Y. Innami, T. Sasaki and K. Hijikata: Proc. Nat. Sci., Nihon Univ., Tokyo, 6 (1971), 1.

29) J. S. Anderson: Nonstoichiometric Compounds, Advances in Chemistry Series 39, Am. Chem. Soc., (1963), 1.

30) A. D. Wadsley: ibid., (1963), 23.

31) S. Anderson, B. Collen, U. Kuylenstierna and A. Magnéli: Acta Chem. Scand., 11 (1957), 1641.

32) M. E. Straumanis, T. Ejima and W. J. James: Acta Cryst., 14 (1961), 453.

33) R. N. Blumenthal, D. H. Whitmore: J. Electrochem. Soc., 110 (1963), 92.

34) I. A. Bursil, B. G. Hyde: Phil. Mag., 20 (1969), 347.

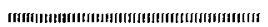

会告

第 11 回案業基礎討論会プログラム

\author{
日時 昭和48年 1 月25日(木)，28日(金) \\ 会場 咸山県総合文化センター（岡山市天神町8-54, 電話 (0862)24-1286) \\ 共催 粉体粉末治金協会 他 \\ 討 論主 題 1 . 相変化一雾国気, 異種成分の影響 \\ 2. セラミックスの微構造と物性
}

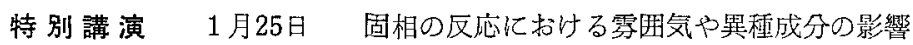

1月26日 セラミックの加工と強度

(東工試) 小 寺嘉㛢

（東工大工材研）斉藤 進 六

\section{一般講 演 $\mathrm{SrO} \cdot 2 \mathrm{FeO} \cdot 8 \mathrm{Fe}_{2} \mathrm{O}_{3}$ の生成時の等囲気之物性 他 42 件}

参加登録費 1,600 円（講演要旨集 1 帆を含む）

予約された方にはあらかじめ講演要旨集を送付しますので，できるだけ予約して下さい，

○予約代金は締切日までに必ず現金書留でで送金下さい。

\section{参加登録の予約申込締切 11月20日（月）}

詳細については下記あてにお問い合わせ下さい。

干700 岡山市津島 岡山大学工学部

高 橋 克 明 電話 (0862) 52-1111 内線 529 